\title{
Economic development of industrial enterprises: motivation-oriented management methods
}

\author{
Oleksandr Husarov ${ }^{1}$, Olena Antyptseva ${ }^{2}$, Kyrylo Husarov ${ }^{3}$, Olga Yurieva ${ }^{4}$ \\ 1,2 Ukrainian Engineering Pedagogics Academy, Department of Management, 16, Universitetskaya \\ str., Kharkiv, 61003 Ukraine \\ ${ }^{3}$ National University of Civil Protection of Ukraine, Educational, Scientific and Production Center, \\ 28, Lermontovskaya str., Kharkiv, 61024 Ukraine \\ ${ }^{4}$ Chief State Auditor-Inspector of Internal Control Department of the Head Department of the State \\ Tax Service in Kharkiv Region, 46, Pushkinskaya str., Kharkiv, 61057 Ukraine
}

\begin{abstract}
The article explores the main approaches to the concept of "motivation-oriented management". The importance of applying motivation-oriented management for the economic development of industrial enterprises is proved. It is determined that the economic development of enterprises is an extremely important factor for the development and competitiveness of the state as a whole. It is noted that in present unstable economic conditions, an innovative approach is necessary for the development of industry. The main and secondary processes that arise in the process of introducing motivational activities in the enterprise are described. It is noted that when managing the economic development of an enterprise, one should focus only on improving its condition, which should be confirmed by certain achieved results. It is indicated that the performance indicators of motivation affect all economic indicators of the enterprise, in particular the level of financial development of industrial enterprises. Conclusions are made regarding the feasibility of introducing motivation-oriented management at Ukrainian enterprises for their economic development.
\end{abstract}

\section{Introduction}

One of the leading sectors of the economy is industry, which is shaping the scientific and technological transformation, economic growth of the country and its social development. Mechanical engineering is the most important industry link in most developed countries of the world. Engineering covers many specialized industries and is the basis of heavy industry and plays a decisive role in developing the material and technical base, and produces tools for various sectors of the national economy. The main way to develop industrial enterprises is to ensure the production of competitive products. 
The formation and strengthening of the competitive advantages of domestic industrial enterprises plays a significant role in increasing the competitiveness of Ukraine. However, there are many internal and external factors that impede this process.

These factors should not prevent increasing the competitiveness of the Ukrainian industry. Ways out of this situation should be constantly searched for, to develop, raise the level of workers, establish contacts with other countries, improve the level of product quality, and introduce new technologies etc.

The aim of the article is to describe motivation-oriented management as a method that plays a significant role in the economic development of Ukraine's industry.

\section{Theory of the matter}

New conditions of development require continuous adaptation of methods and approaches to the assessment of economic development of industrial enterprises, taking into account the rapid changes of the economic space. Theoretical and methodological aspects of managing the economical development of the enterprise were dealt with by such scientists as O. Arefyeva [1], V. Geyets [2], V. Dykan [3], M. Kizim [4], M. Porter [5], V. Prokhorova [6] and others. Problems of motivational-oriented management are considered in the works of such authors as O. Amosov [7], V. Kovalev [8], T. Kuzenko [9], V. Mazur [10], A. Maslow [11], M. Meskon [12] and others.

World experience indicates the transition from management technologies to taking into account the positions of the economy, which significantly affects the maximization of the financial results of enterprises. This necessitates focusing the key tasks of enterprise management on ensuring the competitiveness of the team on the basis of a motivational approach, which directly affects the level of economic development. The above determines the need for an integrated and fundamental approach to assessing the level of motivationoriented financial management of engineering enterprises.

Despite the range of issues that have been studied in the works of foreign and domestic scientists, the problems of developing theoretical and methodological tools for motivationally oriented management of the economic development of industrial enterprises remain insufficiently investigated. The above confirms the relevance of the topic of our study.

\section{Discussion of results}

The functioning of modern enterprises is characterized by uncertainty and dynamism of the socio-economic environment. An effective confrontation of an enterprise with a change is possible only if it implements advanced measures aimed at maintaining viability and ensuring an appropriate level of competitiveness, but this is only possible under conditions of its constant development.

The development of the enterprise consists in making qualitative changes, updating the economic system and organizational structure, increasing the efficiency of functioning by improving technology, technology and labor organization in all structural divisions, improving the quality of products and services.

At the present stage of development of the domestic economy, a significant factor in reducing management efficiency is the lack of effective concepts and applied methods that have improved the process of enterprise development management and increased its profitability both in the short and long term. For the successful development of applied methods and models, it is appropriate to focus primarily on improving the categorical apparatus of the research subject area. Theoretical approaches to the definition of 
"development management" and "economic development" of an enterprise as structural elements of the research subject field are reflected in the works of domestic and foreign scientists and practitioners [6].

We emphasize that when it comes to the economic development of an enterprise, it is necessary to focus only on development in the management process in the understanding of improving its condition, which is characterized by certain achieved results. However, for the implementation of strategic management goals, it is appropriate to formulate tactical tasks that could focus on ensuring the process of determining and adjusting economic indicators and creating conditions for the course of planned processes. An effective solution to the problems of progressive economic development is impossible without awareness of the global organizational and managerial role of motivating factors.

In the organizational and managerial activities of the enterprise, the motivational aspects are becoming increasingly important, because the commercial success of any enterprise depends primarily on how employees realize their potential. The motivational aspect of labor management is widely used in countries with developed market economies.

The motivational mechanism at the enterprise is aimed at surviving and achieving success in a competitive environment [13].

In our opinion, special attention in this matter should be paid to studying the influence of directly motivating factors on the level of economic development of an enterprise, since it is motivation that is the tool that encourages a person to achieve high results in work, and therefore also has significant economic effect.

Studies on the problems of motivation and its methods are reflected in the works of scientific economists A. Maslow [11], A. Bogutsky [14], and others. In addition, out of the field of view of most researchers, there remained questions of the financial expression of the effect of motivational measures in the results of activities and development of the enterprise. Motivation-oriented management of economic development, as an independent direction of scientific research and a type of management activity, was formed as a result of the rapid development of entrepreneurship under the influence of European and world transformational changes, the rapid development of financial relations, the improvement of motivational technologies, and the growing risks of financial losses.

The work of V. Kapitonova [15] provides an interpretation of "economic motivation" as a process combining an employee and an enterprise, in contrast to classical interpretations in which economic motivation is seen as an incentive to action, as a way of rewarding employees, as a process of motivating people to activities at the employer level.

Motivation as an economic category expresses the economic relations between people who participate in the real process of reproduction regarding the realization of motivational potential. The managerial aspect of the motivation for the development of the enterprise lies in the emphasis on creating a certain culture with which the company can effectively solve the problems of external adaptation and internal integration.

The implementation of motivational measures is accompanied by a number of processes, both primary and secondary (aimed at providing) (Fig. 1). Fig. 1 shows that the main motivational process is the formation of a motivational idea and the study of the possibilities of its practical implementation. They are primarily focused on improving the management of enterprises, in particular, their economic development. A managerial decision on the implementation of the developed motivational idea in most cases is made on the basis of the economic efficiency of motivational measures. In the implementation of each of these processes, both primary and secondary, it is advisable to take into account the characteristics of motivational methods.

Considering the organization of the motivation system in enterprises, it is necessary to highlight the existing types of motivational factors of influence on the financial development of the enterprise. Motivational factors influencing financial development can 
be divided into endogenous and exogenous [16]. Endogenous factors of motivation are the motivation of the employee to work activity associated with the content of the work, the level of its significance. If work for an employee is important, useful, then it contributes to the realization of his abilities, leads to an increase in labor productivity.

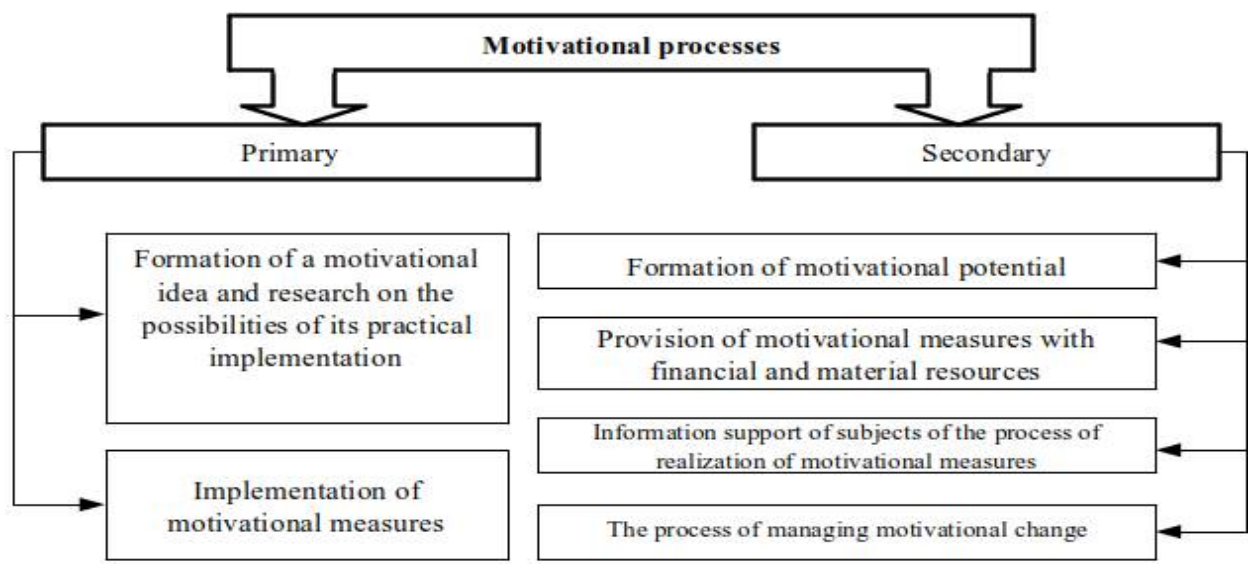

Fig. 1. - Systematization of motivational processes

Exogenous motivation is aimed at stimulating labor on the part of the socio-political system, the regulatory framework and the development of competing enterprises. Moreover, latent factors, intense and extensive, can be distinguished by the degree of influence on financial development; by the nature of the effect: stimulating, destimulating and supporting factors. It should be noted that the performance indicators of motivation affect all economic indicators of the enterprise, in particular the level of economical development of industrial enterprises.

To determine the effectiveness of the introduction of motivation-oriented management of the economic development of the enterprise, it is proposed to use the following criteria:

1. Accuracy of the display of goals. To implement this aspect, it is necessary to provide a quantitative expression of the qualitative content of the goals of the activity and development of the enterprise. With this expression, complex indicators of the economic development of the enterprise appear, and will be further compared with the results of operations. If the quantitative expression of goals is impossible, an assessment of the degree of their achievement in financial values is accepted using the expert method.

2. Compliance with organizational and managerial discipline, regulations and rules. The degree of fulfillment of this criterion characterizes the significance and cyclical nature of errors and failures in the process of performing organizational and managerial tasks, the key aspect of which is motivational support.

3. Accuracy of planning economic indicators. The essence of this criterion is that errors, cost and planned deviations should be monitored through the use of statistical methods of analysis of both indicators of economic activity and the implementation of motivational measures.

4. Effectiveness of economic models.

5. Payback measures of a motivational nature. The costs of organizing incentive events (staff costs, information collection) should be correlated with the economic effect received from them.

This set of criteria is universal, but it can be supplemented and detailed depending on the specifics of the enterprise. 
Thus, from the general spectrum of vectors for managing the financial development of an enterprise, one should single out a motivation-oriented management of the financial development of enterprises to mobilize internal intellectual and competence resources for financial growth and activity in the external economic environment.

The internal result of motivation-oriented management is expressed in the growth of the potential of enterprises and its financial development by increasing the efficiency of using potential on the basis of the mechanism for introducing motivational measures.

Motivation-oriented enterprise management in the external economic environment is assessed by a combination of quantitative and qualitative parameters, including the company's market share, financial stability, business activity dynamics, image of the enterprise, its social activity, readiness to implement research and development, etc.

The structural-logical diagram of the relationship of private elements of the formalization of motivation-oriented management is shown in Fig. 2.

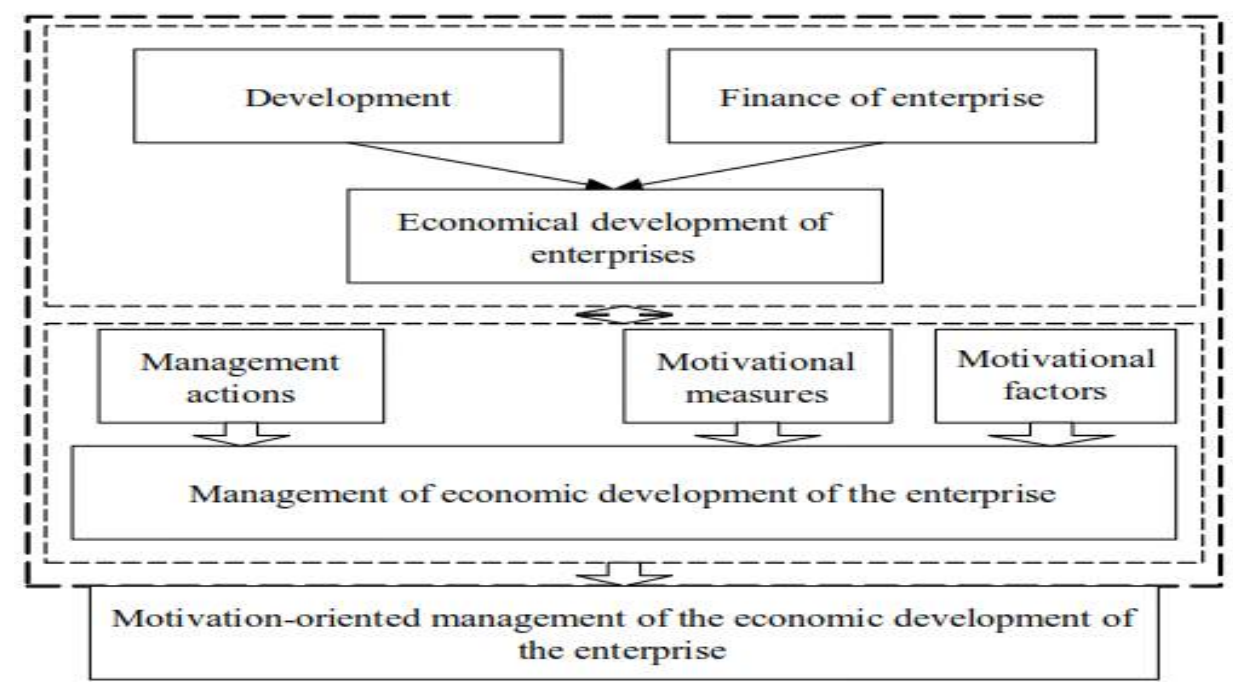

Fig. 2. - The structural-logical diagram of the relationship of the elements of the conceptual-categorical apparatus of the subject field of research of motivation-oriented management of the financial development of the enterprise

The authors determined the essence of motivation-oriented management of the economic development of the enterprise as a system of principles and methods for the development and implementation of managerial decisions, based on the diagnosis of the actual economic condition. Determining the factors that destabilize the sustainability of development and assessing indicators of financial development, allow us to bring the goals and objectives of the enterprise into line with the conditions of the internal and external environment, to ensure a balance between the financial interests of the enterprise and the need for our employees, through effective management actions, taking into account motivational factors in the process of transition to a new improved economic level.

The effectiveness of motivation-oriented management of the economic development of an enterprise is manifested in the dynamics of its development, namely: achievement of strategic goals that reflect natural and cost indicators, in the effective use of financial potential, expanding markets for products and replenishing the client base through effective motivational policies. 


\section{Conclusion}

Thus, as a result of the our study, an analysis was made of the motivational factors of the influence of the external and internal environment on the economical development of the enterprise, which are important in constructing strategic plans for the development of business entities in modern conditions of the development of the knowledge economy, among the priority areas of which the motivational direction is distinguished.

After all, by taking into account the above factors to improve the financial effect of motivational measures, it is possible to adjust the influence of these factors and, thus, to improve the efficiency of activity and economical development of enterprises. Based on the results of the study, it can be argued that a well-designed organizational and management activities to implement motivational measures and taking into account the influence of motivational factors can create a sense of personal financial contribution to the activities of the entity.

In our opinion, effective motivational measures should ensure the successful transformation of a set of factors, principles, incentives, motives, value orientations, expectations, behavioral reactions from a linear discrete state into a closed, constantly repeating process with a tangible financial result in the strategic aspect of the economic development of the enterprise.

\section{References}

1. Arefyeva O. Upravlinnia rozvytkom ekonomichnykh system: teoriia, mekhanizmy rehuliuvannia ta upravlinnia: monohrafiia [Management of economic systems development: theory, mechanisms of regulation and management: monograph]. Kharkiv : UkrDAZT (In Ukrainian). (2010)

2. Geyets V. Suspilstvo, derzhava, ekonomika: fenomenolohiia vzaiemodii ta rozvytku [Society, state, economy: phenomenology of interaction and development]. Kyiv : NAS of Ukriane (In Ukrainian) (2009)

3. Dykan V. Ekonomyka predpryiatyia: uchebnoe posobye [Enterprise Economics: A Training Manual]. Kharkiv : UkrDAZT (In Russian). (2008)

4. Kizim M. Vysokotekhnolohichnyi sektor ekonomiky Ukrainy ta krain svitu: stan i tendentsii rozvytku [High-tech sector of economy of Ukraine and countries of the world: state and tendencies of development]. Problems of Economy №3 (In Ukrainian). (2009)

5. Porter M. Competitive strategy. Measuring business excellence. (In English). (1997)

6. Prokhorova V. Ekonomichnyi rozvytok pidpryiemstva: teoretyko - metodolohichnyi aspekt [Economic development of the enterprise: theoretical and methodological aspect]. Kharkiv: UkrDAZT (In Ukrainian). (2010)

7. Amosov O. Otsinka potentsialu konkrentospromozhnosti yak osnovnoho aspektu rozvytku pidpryiemstva [Assessment of competitive potential as a major aspect of enterprise development]. Problems of Economy (In Ukrainian). (2011)

8. Kovalev V. Rol truda v formirovanii obschestvennyh otnoscheniy. [The role of labor in the formation of social relations]. Kharkiv: NTMT (In Russian). (2015)

9. Kuzenko T. Optymizatsiia rivnia finansovoho rozvytku pidpryiemstva na osnovi taksonomichnoho analizu. [Optimization of the level of financial development of the enterprise on the basis of taxonomic analysis]. Kyiv : NAU (In Ukrainian). (2015)

10. Mazur V. Vdoskonalennia system motyvatsii pratsi. [Improvement of work motivation systems]. Ternopil: ANG (In Ukrainian). (2008)

11. Maslow A.A. Theory of Human Motivation. Psychological Review, vol. 50, pp. 370-396 (1943) 
12. Meskon M. Management: Individual and Organizational Effectiveness. USA: Harper \& Row. (1985)

13. Gergesha Y. Strukturno-funktsionalne modeliuvannia stratehichnoho upravlinnia finansovym rozvytkom pidpryiemstva [Structural and functional modeling of strategic management of financial development of the enterprise]. Development Management: A Collection of Scientific Papers (In Ukrainian). (2011)

14. Bogutsky A. Faktory rozvytku motyvatsii pratsi. [Factors of development of work motivation]. APK Economics (In Ukrainian). (2005)

15. Kapitonova V. Motivatsyonnaya sreda kak instrument aktivizatsii korporativnoy kultury na promyshlennom predpryiatii [Motivational environment as a tool to enhance corporate culture in an industrial enterprise]. Izhevsk: GTA. (In Russian). (2012).

16. Shakhovoy V. Motyvatsyia trudovoi deiatelnosty: Uchebno-metodycheskoe posobye [Motivation of work: educational-methodical manual]. Moscow: Alpha-press. (In Russian). (2006). 